\title{
Water parameters and primary productivity at four marine embayments of Costa Rica (2000-2002)
}

\author{
José A. Vargas-Zamora ${ }^{* 1,2}$, Jenaro Acuña-González ${ }^{1,3,4}$, Jeffrey A. Sibaja-Cordero ${ }^{1,2}$, \\ Eddy H. Gómez-Ramírez ${ }^{1,4}$, Grettel Agüero-Alfaro ${ }^{1} \&$ Jairo García-Céspedes ${ }^{1}$ \\ 1. Centro de Investigación en Ciencias del Mar y Limnología (CIMAR), Universidad de Costa Rica, 11501-2060, San \\ José, Costa Rica; jose.vargas@.ucr.ac.cr \\ 2. Escuela de Biología, Universidad de Costa Rica, 11501-2060, San José, Costa Rica. \\ 3. Centro de Investigación en Contaminación Ambiental (CICA), Universidad de Costa Rica, 11501-2060, San José, \\ Costa Rica. \\ 4. Escuela de Química, Universidad de Costa Rica, 11501-2060, San José, Costa Rica. \\ * Correspondence
}

Received 02-VIII-2017. Corrected 11-I-2018. Accepted 25-I-2018.

\begin{abstract}
The availability of baseline data on water parameters and primary productivity is essential in comparative studies aimed at identifying environmental trends, like eutrophication, in coastal embayments. In this context, the objetive of this work is to make accessible data, collected from 2000 to 2002, on 13 water parameters (Secchi depth, temperature, salinity, dissolved oxygen, oxygen saturation, suspended matter, chlorophyll- $a$, phaeopigments, phosphate, silicate, ammonium, nitrite and nitrate) their temporal and spatial distribution, and primary productivity at four coastal sites of Costa Rica. The multi-parameter survey was conducted based on surface ( $1 \mathrm{~m}$ deep) water samples collected at a total of 128 stations at three Pacific and one Caribbean embayments: a bay under the influence of upwelling (Culebra Bay), a tidal estuary (Gulf of Nicoya), a semi-enclosed small coastal bay bordered by mangroves (Golfito Bay), and a Caribbean bay and port (Moin Bay). Graphic distributions of stations from the four embayments and for the Gulf of Nicoya were obtained by Principal Component Analysis (PCA). PCA Gabriel biplots were used to illustrate the relative importance of each parameter on the separation of stations. The four embayments were separated by PCA based on the 13 parameters. The maximum values recorded were: Secchi depth: $12.6 \mathrm{~m}$; salinity: $35 \mathrm{psu}$; temperature: $32.5^{\circ} \mathrm{C}$; oxygen: 11.4 $\mathrm{mg} / \mathrm{L}$; oxygen saturation: $188 \%$; suspended matter: $156.04 \mathrm{mg} / \mathrm{L}$; chlorophyll- $a$ : $16.21 \mathrm{mg} / \mathrm{m}^{3}$; phaeopigments: $6.37 \mathrm{mg} / \mathrm{m}^{3}$; phosphate: $9.53 \mu \mathrm{mol} / \mathrm{L}$; silicate: $156.11 \mu \mathrm{mol} / \mathrm{L}$; ammonium: $2.66 \mu \mathrm{mol} / \mathrm{L}$; nitrite: $2.47 \mu \mathrm{mol} / \mathrm{L}$; and nitrate: $4.59 \mu \mathrm{mol} / \mathrm{L}$. Salinity and several nutrients varied seasonally (dry $v s$ rainy) in the Gulf of Nicoya estuary. Estimates of net primary productivity (Winkler oxygen method) produced a maximum $2206 \mathrm{~g} \mathrm{C} / \mathrm{m}^{2} /$ year at Culebra Bay. The maximum net PP $\left(\mathrm{g} \mathrm{C} / \mathrm{m}^{2} /\right.$ year) at the other three embayments, were: 1601 (Gulf of Nicoya), 1371 (Golfito Bay), and 1100 (Moín Bay). Net PP values showed high variability in space and time, and ranged from negative to those associated with oligotrophic, eutrophic, and hypertrophic waters. In the Gulf of Nicoya $60 \%$ of the values of net PP exceeded the reference value $\left(500 \mathrm{~g} \mathrm{C} / \mathrm{m}^{2} /\right.$ year $)$ to separate eutrophic from hypertrophic conditions. Rev. Biol. Trop. 66(Suppl. 1): S211-S230. Epub 2018 April 01.
\end{abstract}

Key words: nutrients, chlorophyll- $a$, eutrophication, estuary, upwelling, Eastern Pacific, Caribbean.

Coastal development in Costa Rica increased drastically towards the end of the $\mathrm{XX}^{\text {th }}$ Century, and information on water conditions, water dynamics, and concentrations of nutrients and pollutats was urgently needed. Thus, an ecological assesssment was started in 2000 at four coastal marine embayments of Costa Rica, and the sudy of water characteristics, concentration of pollutants and primary productivity estimates, were part of the study. Three embayments were located along the Pacific coast and the fourth on the Caribbean coast. The results of 
this research have been published mostly by the Revista de Biología Tropical, as part of the series Ecosystems of Costa Rica, as in this case.

The tidal currents in the Gulf of Nicoya were studied by Lizano \& Alfaro (2004). Data on concentrations of Poly-Chlorinated Biphenyls (PCBs) in sediments and tissues of sipunculan worms were discussed by Spongberg (2004 a, b, c; 2006); a review of the literature on PCB concentrations in tropical media was published by Spongberg \& Witter (2008). Concentrations of petroleum hydrocarbons in waters were determined by Acuña-González, Vargas-Zamora, Gómez-Ramírez, \& GarcíaCéspedes (2004). The presence of coliform bacteria in waters and beach litter at the four sites were reported by García, Acuña-González, Vargas-Zamora, \& García-Céspedes (2006). The impact of certain pollutants as potential endocrine disruptors of coastal organisms was reported by Cheek (2006), and Valverde, Selcer, Lara, \& Sibaja-Cordero (2008). Gravel, Johanning, McLachlan, Vargas, \& Oberdörster (2006) published the first report for Central America on imposex in the intertidal snail Acanthais brevidentata. As a follow-up of the evaluation of trace compounds, Spongberg et al. (2011) reported the presence of Pharmaceutical and Personal Care Products (PPCPs) in rivers flowing into the four embayments and other coastal sites.

Data on the ecology of selected coastal organisms from the embayments were published by Sibaja-Cordero \& Vargas-Zamora (2006) and by Rojas-Figueroa \& Vargas-Zamora (2008). As part of the study, the lists of polychaete and sipunculan worms found in Costa Rica were updated with the goal of identifying potential pollution-indicator species (Dean, 2004; 2009; Vargas \& Dean, 2009). The use of polychaetes as indicators of pollution in tropical sites was further discussed by Dean (2008). Data on trace metals in sediments from the four embayments were summarized by GarcíaCéspedes, Acuña-González, \& Vargas-Zamora (2004), while Vargas, Acuña-González, Gómez, \& Molina (2015) published data on trace metals from snails (including $A$. brevidentata) and clams collected at the four sites. More recently Vargas, Acuña-González, Vásquez, \& SibajaCordero (2016) reported on the abundances and concentrations of trace metals in tissues of the sipunculan, Sipunculus nudus and the lingulide brachiopods, Glottidia audebarti and Glottidia albida from a sand flat in the upper Gulf of Nicoya.

Thus, the objective of this report is to make accessible data collected on water parameters, their temporal and spatial distribution, and on primary productivity, gathered during the 2000-2002 environmental assessment of four coastal sites of Costa Rica.

\section{MATERIALS AND METHODS}

Study sites: The four coastal embayments sampled in this study differ in the extent of their geographical area. The Gulf of Nicoya has the greatest area, followed by Culebra Bay, Golfito Bay, and Moín Bay. Three of the sampling sites (Culebra Bay, Gulf of Nicoya, and Golfito Bay) are located along the Pacific coast of Costa Rica (Fig. 1A), where mean tidal range is near $3 \mathrm{~m}$. The fourth site, Moín Bay, is on the mid Caribbean coast (Fig. 1A), where mean tidal range is usually less than $0.5 \mathrm{~m}$.

Culebra Bay is an embayment on the Northern Pacific coast of Costa Rica and its mouth opens into the Gulf of Papagayo (Fig. 1B), an upwelling region. No major river or creek flows into Culebra Bay. The shores are the sites for many tourism facilities that benefit from numerous white sandy beaches and coral patches (Jiménez, 2001). The Bay has a maximum depth of $30 \mathrm{~m}$ at its mouth. Three sampling stations were located inside the Bay in front of Esmeralda, Panamá, and Nacascolo beaches (Fig. 1B).

The Gulf of Nicoya is an estuary on the central Pacific coast of Costa Rica (Fig. 1C). Since the Mid- $20^{\text {th }}$ Century the Gulf has been the main fishing ground of the country for finfish and shellfish. Puntarenas and Caldera, located on the middle Gulf, are the most important ports on the Pacific coast. The estuary is under the influence of seasonal rainfall 

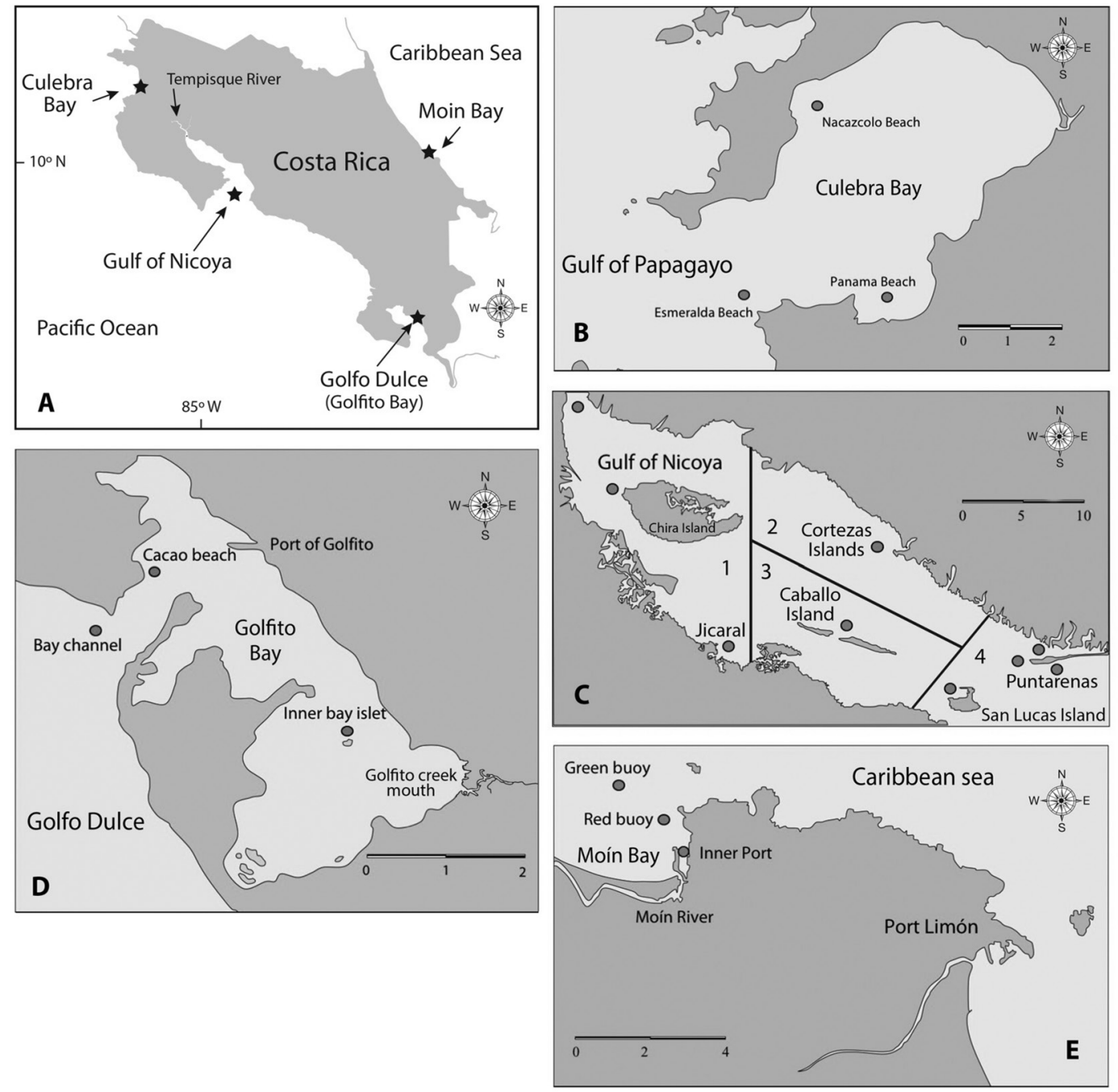

Fig. 1. A: Location of the four coastal embayments on the Pacific and Caribbean coasts of Costa Rica, 2000-2001-2002. B. Gulf of Papagayo, Culebra Bay $\left(10^{\circ} 62^{\prime} \mathrm{N}-85^{\circ} 66^{\prime} \mathrm{W}\right)$ Panamá beach, Nacascolo beach, Esmeralda beach. C. Gulf of Nicoya estuary $\left(10^{\circ} 00^{\prime} \mathrm{N}-85^{\circ} 00^{\prime} \mathrm{W}\right)$ : 1- Upper region, 2- Cortezas islands, 3- Caballo island, 4- Lower region. D. Northern shore of Golfo Dulce, Golfito Bay ( $\left.83^{\circ} 10^{\prime} \mathrm{N}-8^{\circ} 35^{\prime} \mathrm{W}\right)$ Bay channel, Cacao beach, Inner islet. E. Container ship port of Moín ( $10^{\circ} 00^{\prime} \mathrm{N}-83^{\circ} 07^{\prime}$ W) Green navigation buoy, Red navigation buoy, Inner Moín Port B-E. Scale bars in km.

(May to November) followed by a dry season (December to April). Wind is also important as a water mixing force mainly during the early dry season. Depths at low tide in the upper Gulf range from about $40 \mathrm{~m}$ between Chira Island and the Port of Puntarenas, to less than $2 \mathrm{~m}$ near the mouth of the Tempisque River (Fig. 1C). As for this study the Gulf was divided into four regions: upper (near the mouth of the
Tempisque River, including Chira Island and Jicaral estuary), middle right (mear Cortezas islands and the Punta Morales port), middleleft (near Caballo Island) and lower region, near the port city of Puntarenas and San Lucas Island (Fig. 1C).

Golfito Bay is a small, shallow (less than $5 \mathrm{~m}$ at low tide) and semi-enclosed embayment on the Northern shore of Golfo Dulce, the main 
gulf in the Southern Pacific coast of Costa Rica (Fig. 1D). The Golfo Dulce region has heavy rains year around. Golfito Bay is the site of the main port of Golfo Dulce and the bay is bordered mostly by red mangroves along most of its shores. Golfito Bay receives freshwater input from many small creeks and the sewerage system of the port city. Two sampling stations were deployed at the mouth of Golfito Bay and one station near the Pelícano islet on the upper bay region (Fig. 1D).

Moín Bay is on the central Caribbean coast of Costa Rica and is directly exposed to the Caribbean Sea (Fig. 1E). The Moín River runs parallel to the shore and is bordered by mangroves. Brackish waters are found at the river mouth (Mata, Acuña, Murillo, \& Cortés, 1987). The Moín port houses the main Caribbean facilities for docking of small fuel tankers and container ships, and is under the process of further development. Depths range from about $10 \mathrm{~m}$ inside the port to near $25 \mathrm{~m}$ at the port entrance. Sampling stations included one near the main dock, and two along the navigation channel (green and red buoys in Fig. 1E).

Water parameters: A total of 128 water stations were taken at the four embayments: 68 on the Gulf of Nicoya estuary, 30 on Moín Bay, 19 on Golfito Bay, and 11 on Culebra Bay. The term station is used here to mean a geographical sampling point (located by GPS coordinates) where water samples were taken at a given date and time of the day. For each station, 13 parameters were recorded: 1 . Light penetration, 2. Water temperature, 3. Salinity, 4. Dissolved oxygen, 5. Oxygen saturation, 6. Chlorophyll- $a$, 7. Phaeopigments, 8. Suspended matter, 9. Ammonium, 10. Nitrite, 11. Nitrate, 12. Phosphate and, 13. Silicate. The stations were reached by an inflatable boat, and a hand operated winch was used to handle the sampling equipment.

The penetration of light in the waters was estimated by the use of a $0.3 \mathrm{~m}$ diameter Secchi disk and following Holmes (1970). Water samples were collected with a 5 L oceanographic General Oceanics ${ }^{\circledR}$ Niskin bottle at 1 $\mathrm{m}$ depth. The water-filled closed Niskin bottle was brought aboard and temperature and dissolved oxygen were measured in the bottle with a probe of a calibrated Yellow Springs ${ }^{\circledR}$ Instrument Model 57 Oxygen meter, after compensating for salinity. Percent oxygen saturation was also computed. Water salinity was determined from drops of seawater placed on a calibrated (Standard Sea Water) American Optical ${ }^{\circledR}$ refractometer. Water samples from the Niskin bottle were transferred to dark plastic $2.5 \mathrm{~L}$ bottles and placed in a cooler filled with ice and transported to the nearby ground facility. Water samples were filtered at the field laboratory and the glass microfibre filters were folded, placed in plastic bags and preserved on ice for chlorophyll- $a$ and suspended matter determinations following Strickland \& Parsons (1972). A Shimadzu ${ }^{\circledR}$ UV-1700 spectrophotometer was used for the determination of chlorophyll- $a$ and phaeopigments. Filtered water samples for nutrient analyses were kept in dark plastic $0.5 \mathrm{~L}$ bottles and stored in a freezer $\left(-18{ }^{\circ} \mathrm{C}\right)$ until analysis. Spectrophotometric (Shimadzu UV-1700) determination of ammonium, nitrite, nitrate, phosphate, and silicate concentrations were carried out in triplicate (10 mL samples) following methods based on Strickland \& Parsons (1972) and validated protocols in use at the UCR-CIMAR Chemical Oceanography Laboratory. Before each batch of samples was analyzed, calibration curves were run for each analyte and the detection limits were obtained according to Meier \& Zünd (1993).

Primary productivity: Water column productivity was estimated at selected stations at the four sites using the light and dark bottles method, determining changes in dissolved oxygen concentrations, as in Riley \& Chester (1971), and Strickland \& Parsons (1972). Oxygen chemical determinations were performed according to the modified Winkler method (Gocke, Cortés, \& Villalobos, 1990). Plastic rims were designed to hold the set of bottles for a selected depth, and the set of rims was kept in place by an anchor weight at the bottom and a buoy at the surface. Depths for the incubation of two dark and two clear volume-calibrated $300 \mathrm{~mL}$ BOD bottles, plus two clear bottles 
as reference, were selected based on the depth of the Secchi disk at the site, and on the light extinction exponential equation using an extinction coefficient $\mathrm{k}=1.7$, as indicated by Holmes (1970). Also, depending on the bottom depth, two to five incubation rims of light and dark BOD bottles representing from $100 \%$ to $1 \%$ of the incident light were selected. The incubation period lasted three hours on the average, and usually one period in the morning and another in the afternoon were accomplished. To convert data from mg of oxygen to mg of carbon, a photosynthetic coefficient of 1.2 and a respiration coefficient of 0.83 were used based on Gocke et al. (1990).

Statistical analyses: All statistical analyses were carried out with software PAST (Hammer, Harper, \& Ryan, 2001).

A. The four sites: A between groups Principal Component Analysis (PCA) was computed with the standardized ( $z$ scores) values for the 13 parameters of stations sampled at the four embayments, with a star representing the centroid for the group of stations from an embayment (Culebra Bay, Gulf of Nicoya, Golfito Bay, Moín Bay). Ellipses were computed to include stations from an embayment within 95 $\%$ confidence limits. A PCA Gabriel biplot was also computed to illustrate the relative importance of each parameter on the grouping of stations representing the embayments (Dolédec, \& Chessel, 1991; Hammer et al., 2001; Legendre, \& Gallagher, 2001). To evaluate for spatial differences in the environmental parameters found by PCA, two PERMANOVA (Anderson, 2001) tests were computed with a posteriori comparisons and 9999 permutations. Two matrices were employed: An Euclidean distance matrix based on the standardized environmental values for Gulf of Nicoya only, and another matrix of standardized values of the parameters of the four embayments.

B. The Gulf of Nicoya: Two groups of similar number of stations taken during the dry and rainy seasons in regions 1,2 and 3 (Fig. 1C) of the Gulf of Nicoya estuary were selected to test for seasonality of the 13 parameters measured. Seasonality was evaluated by means of a MannWhitney U test comparing medians (Conover, 1971). A between groups PCA was computed as a graphic display of stations sampled in the Gulf. In order for the software to run properly, all data on concentrations with values below the detection limit were included in the data matrix as 0.00 . Data was standardized to $z$ scores before computing PCA. The centroid for each group of stations from a region (Upper, Middle right, Middle left, Lower) was represented by a star, and a hand-drawn polygon enclosed all stations for a region. A PCA Gabriel biplot was computed to illustrate the relative importance of each parameter on the group of stations representing a region (Dolédec \& Chessel, 1991; Hammer et al., 2001; Legendre \& Gallagher, 2001).

C. Primary productivity: A Spearman rho rank correlation (Conover, 1971) was computed between depth-integrated net primary production per day (Net PP/day) and each of the 13 environmental parameters.

\section{RESULTS}

A. The four sites: Code numbers for the 128 stations taken at the four sites and date of collection are included in Table 1. Results of the PCA performed on the total of 128 stations sampled at the four embayments are included in Fig. 2A. Three stations from the Gulf of Nicoya $(14,92,102)$ are outside the $95 \%$ confidence limits. The PCA separation of the four embayments included three (Gulf of Nicoya, Culebra Bay and Golfito Bay) with stations that stand alone in one of the sides of their ellipses (and maximizing the differences), while the centroid for the Moín Bay stations was near the other three centroids (Fig. 2A). Moreover, Moín was separated by a third axis (PC-3, not plotted) that explains $6 \%$ of the variation. The PERMANOVA test confirmed that the four embayments could be separated based on their environmental parameters $(\mathrm{F}=9.0, \mathrm{p}<0.001)$. However, the 
TABLE 1

Coastal embayments, station sites, $\mathbf{N}=$ total number of stations per embayment. Station code number (bold) and date (month-day-year). Pacific (Gulf of Nicoya, Culebra Bay, Golfito Bay) and Caribbean (Moin Bay) coasts of Costa Rica. 2000-2001-2002. Total number of surface (1 m depth) stations: 128

\section{Culebra Bay $\quad$ Panama Beach, Nacascolo Beach, Esmeralda Beach. N = 11}

59 (Jun. 28-00), 60 (Jun. 28-00), 61 (Jun. 29-00), 62 (Oct. 19-00), 63 (Oct. 18-00), 64 (Oct. 19-00), 65 (May 24-01), 66 (May 24-01), 67 (Jun. 28-00), 68 (Oct. 18-00), 128 (May 24-01)

\section{Gulf of Nicoya}

Upper Gulf, Middle Gulf, Lower Gulf. $\mathbf{N}=68$

Upper Gulf of Nicoya region, Tempisque river mouth and West of Chira Island. $\mathrm{N}=16$

82 (Jul. 27-00), 87 (Apr. 06-01), 88 (Apr. 06-01), 93 (Jun. 21-01), 94 (Jun. 21-01), 96 (Oct. 12-01), 97 (Oct. 12-01), 101 (Feb. 14-02), 102 (Feb. 14-02), 103 (Feb. 14-02), 105 (Mar. 21-02), 106 (Mar. 21-02), 108 (May 03-02), 109 (May 03-02), 111 (Jun. 13-02), 112 (Jun. 13-02)

Upper Gulf of Nicoya region, Jicaral. $\mathrm{N}=8$

83 (Jul. 27-00), 86 (Apr. 06-01), 92 (Jun. 21-01), 95 (Oct. 12-01), 100 (Feb. 14-02), 104 (Mar. 21-02), 107 (May 03-02), 110 (Jun. 13-02)

\section{Middle Right Gulf of Nicoya region, Cortezas islands. $\mathrm{N}=27$}

01 (Jul. 27-00), 02 (Jun. 21-01), 03 (Oct. 12-01), 04 (Feb. 14-02), 05 (Mar. 21-02), 06 (May 03-02), 07 (Jun. 13-02), 13 (Mar. 22-00), 14 (Mar. 22-00), 15 (Mar. 22-00), 16 (Apr. 12-00), 17 (Sep. 01-00), 18 (Sep. 01-00), 69 (Apr. 12-00), 70 (Apr. 12-00), 71 (Apr. 12-00), 72 (Apr. 12-00), 73 (Sep. 01-00), 74 (Sep. 01-00), 75 (Sep. 01-00), 76 (Sep. 01-00), 77 (Sep. 01-00), 90 (Apr. 06-01), 98 (Oct. 12-01), 99 (Feb. 14-02), 113 (Jul. 19-02), 114 (Jul. 19-02)

Middle Left Gulf of Nicoya region, Caballo Island. $\mathrm{N}=6$

08 (Feb. 14-02), 09 (Mar. 21-02), 10 (May 03-02), 11 (Apr. 12-00), 12 (Apr. 05-01), 19 (Sep. 01-00)

Lower Gulf of Nicoya region, Puntarena port and San Lucas Island. $\mathrm{N}=11$

78 (Apr. 11-00), 79 (Aug.31-00), 80 (May 04-00), 81 (May 04-00), 84 (Jul. 27-00), 85 (Jul. 27-00), 89 (Apr. 06-01), 91 (Apr. 04-01), 115 (Jul. 19-02), 116 (Jul. 19-02), 117 (Jul. 19-02)

\section{Golfito Bay}

Bay channel, Cacao Beach, Inner bay islet. $\mathrm{N}=19$

20 (May 10-00), 21 (May 10-00), 22 (May 10-00), 23 (May 10-00), 24 (Nov. 29-02), 25 (Nov. 22-00), 26 (Nov. 27-01), 27 (Nov. 27-01), 28 (Nov. 29-02), 29 (Nov. 29-02), 30 (Feb. 07-02), 31 (May 10-00), 32 (Feb. 07-02), 33 (May 10-00), 34 (Feb. 07-02), 35 (Nov. 27-01), 36 (Nov. 24-00), 118 (Nov. 23-00), 119 (Nov. 23-00)

\section{Moin Bay Inner port, Red buoy, Green buoy. $\mathbf{N}=\mathbf{3 0}$}

37 (Mar. 07-02), 38 (Jan-17-02), 39 (Jan-17-02), 40 (Jan-17-02), 41 (May 10-01), 42 (May 10-01), 43 (May 10-01), 44 (Mar. 30-01), 45 (Mar. 30-01), 46 (Feb. 07-01), 47 (Feb. 07-01), 48 (Feb. 07-01), 49 (Feb. 07-01), 50 (Oct. 04-00), 51 (Oct. 05-00), 52 (Oct. 05-00), 53 (Aug.16-00), 54 (Aug.16-00), 55 (Aug.16-00), 56 (May 25-00), 57 (May 25-00), 58 (May 25-00), 120 (May 25-00), 121 (Oct. 04-00), 122 (Mar. 07-02), 123 (Mar. 07-02), 124 (Mar. 07-02), 125 (Jul. 07-02), 126 (Jul. 07-02), 127 (Jul. 07-02)

four sites also presented several stations that overlapped in their values (Fig. 2A).

Results of the PCA Gabriel biplot for the 128 stations are included in Fig 2B. Some Culebra Bay stations appeared to cluster more along the line representing higher Secchi depth and salinity, while some stations from the Gulf of Nicoya clustered along the lines representing higher nitrate, phosphate, phaeopigments and chlorophyll- $a$. Several stations from Golfito Bay seemed to follow the lines for increasing temperature and concentrations of oxygen, silicate, ammonium. Stations from Moín bay, however, were foundto group with higher values of salinity and Secchi depth and lower chlorophyll- $a$ and phaeopigments than the Gulf of Nicoya. 

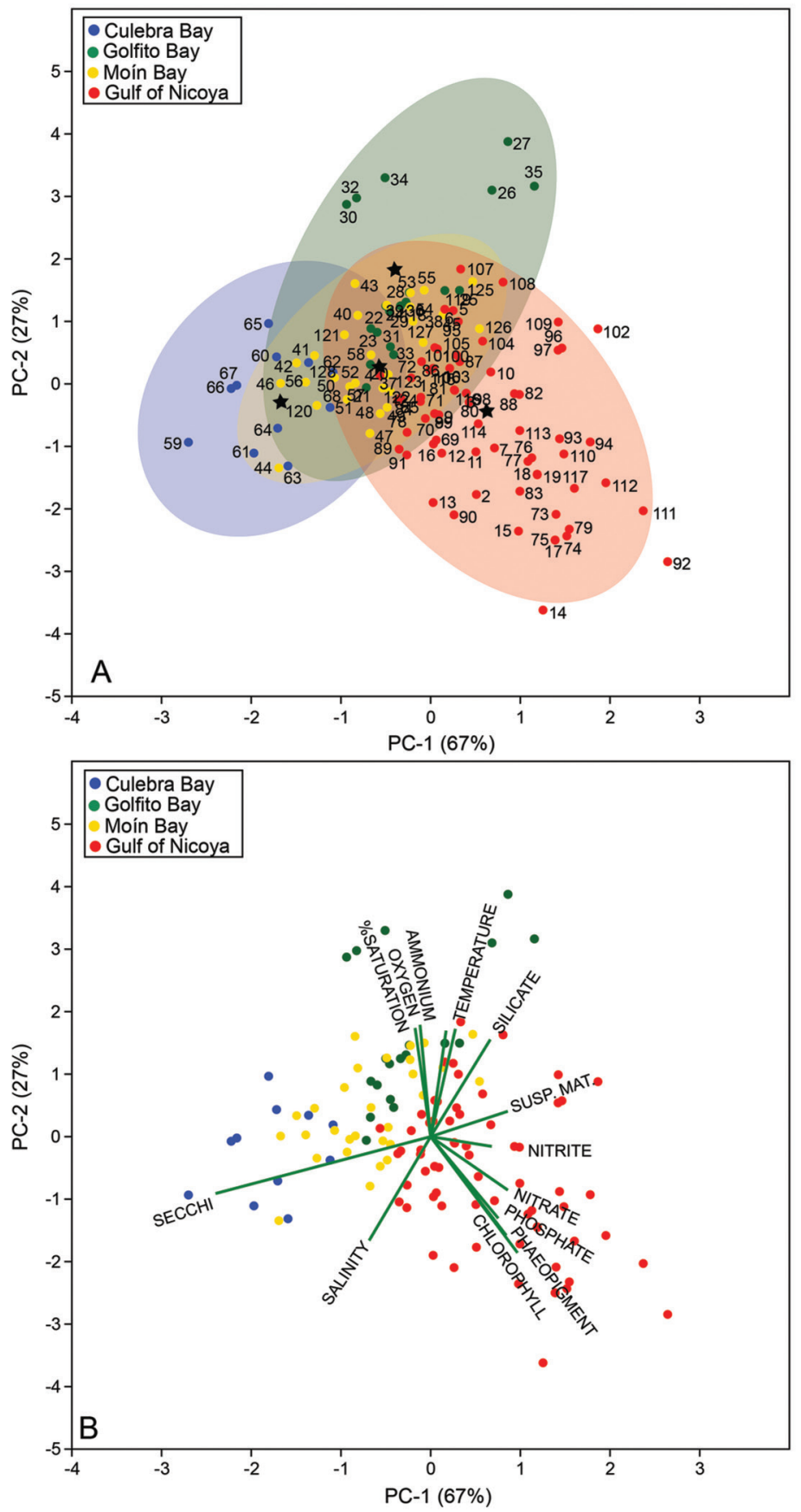

Fig. 2. The four-embayment groups of stations: Between Groups Principal Component Analysis (PCA) performed on 13 parameters (Secchi depth, salinity, temperature, dissolved oxygen, oxygen saturation, suspended matter, chlorophyll- $a$, phaeopigments, phosphate, silicate, ammonium, nitrite, and nitrate) at 118 surface (1 m depth) water stations in the Pacific (Culebra Bay, Gulf of Nicoya, Golfito Bay) and Caribbean coasts (Moin Port Bay) of Costa Rica. 2000-2002. A. Separation of the four-embayment groups of stations. The centroid for each group is indicated by a star. Ellypses represent $95 \%$ confidence intevals. B. PCA biplot. Vectors indicating relative importance of parameters are represented by radiating lines. 
Examples of stations $(26,27,28,32,44,47$, $45,46,48,49,59,62,63,66,67,64,119)$ from the other three bays (Golfito, Culebra, Moín) are listed in Table 2. Parameters for stations 92102 and others from the Gulf of Nicoya are included in Table 3.

B. Gulf of Nicoya: The list of the 68 stations taken on the Gulf of Nicoya is included in Table 1. The maximum and minimum values for the 13 parameters, their means, medians, standard errors, standard deviations, and the 25 and 75 percentiles, as well as selected examples of representative stations, are included in Table 3.

Results of the PCA performed on the 68 stations from the Gulf of Nicoya indicate that PC-1 and PC-2 explained $90 \%$ of the variance (Fig. 3A). A gradient of change was found for the environmental parameters from Upper to Lower region following the PC-1. PC-2 separated the Middle region from the Upper and Lower regions of the estuary.

Results of the PCA Gabriel biplot for the Gulf are included in Fig 3B, and indicate three main parameter trends for station separation: 1- Secchi depth, salinity and nitrate (with higher values in the Lower region), 2- Percentage of dissolved oxygen saturation, chlorophyll- $a$ and phaeopigments (with higher values at the Middle of the Gulf) and, 3- Temperature, suspended matter, phosphate, silicate, and nitrite (higher values in the Upper region).

Results of the Mann-Whitney U test, performed on a set of 49 stations (25 during the dry season and 24 during the rainy season) from the Gulf of Nicoya are included in Table 4. The $\mathrm{U}$ test detected seasonal differences (dry vs rainy, $\mathrm{p}<0.05$ ) for: salinity, dissolved oxygen, and the percentage of dissolved oxygen saturation, with higher values during the dry seasons. Phosphate, silicate, and nitrite, had higher concentrations during the rainy seasons. No seasonal differences were found for the other seven parameters (Table 4).

There was a gradual change in the parameter values within the estuary (PERMANOVA, $\mathrm{F}=3.39, \mathrm{p}=0.0001)$. The Lower region was

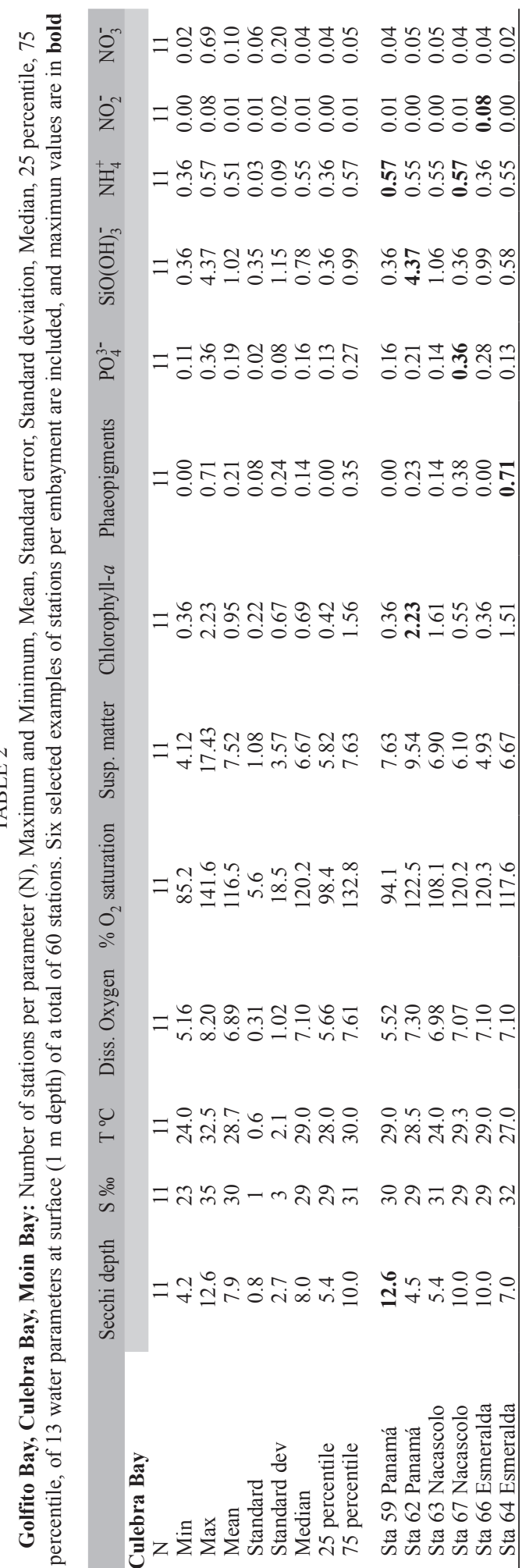




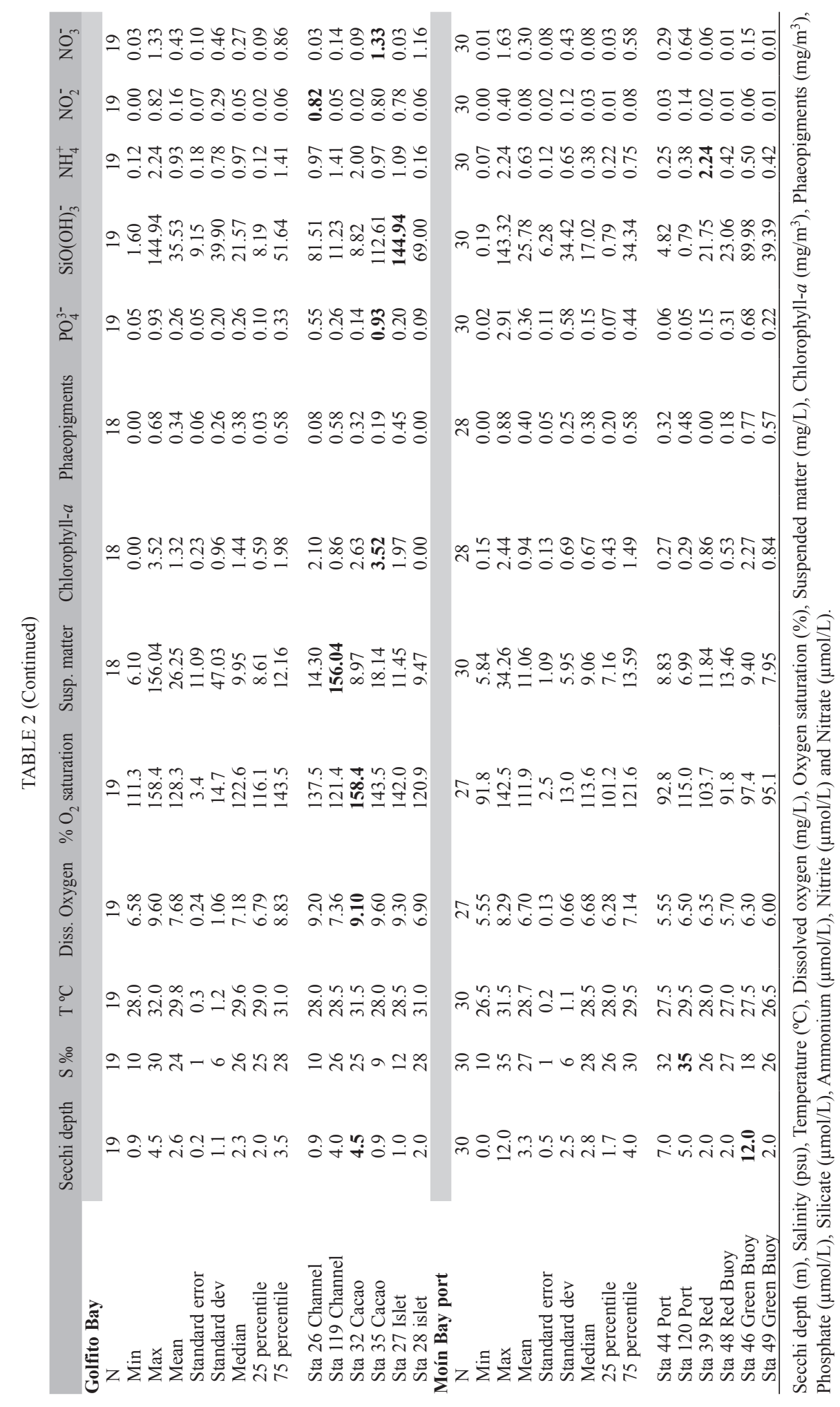




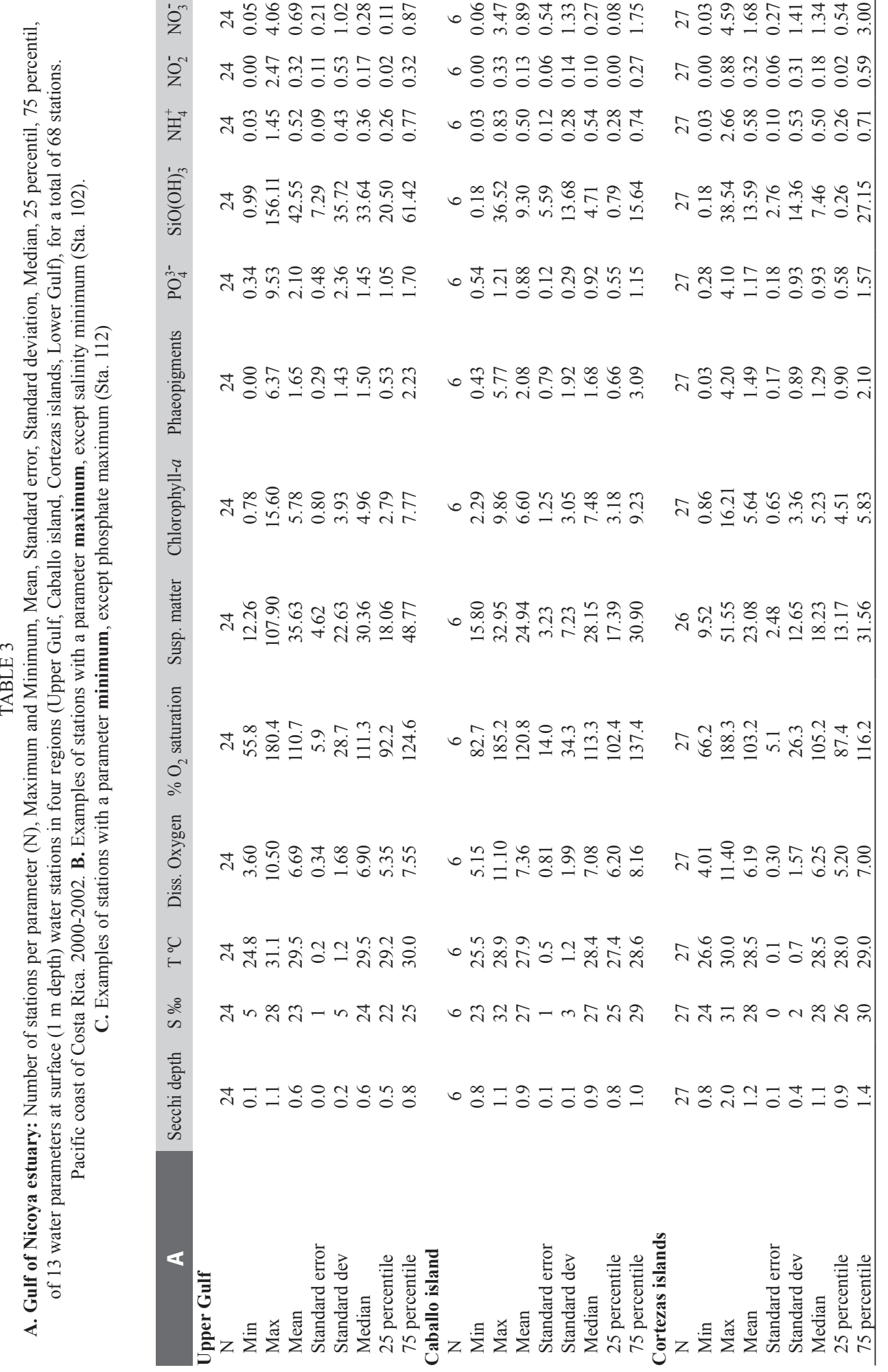




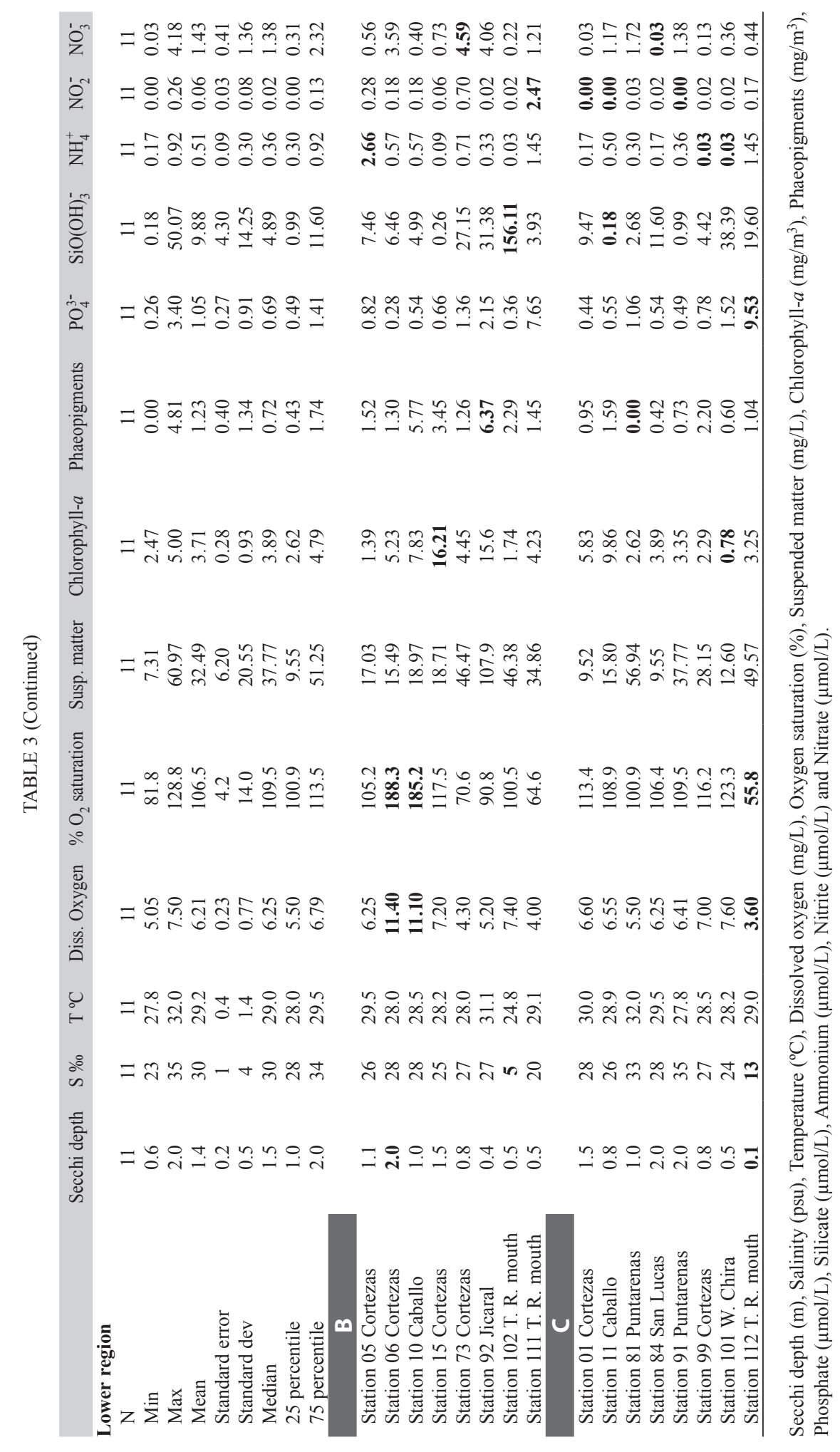



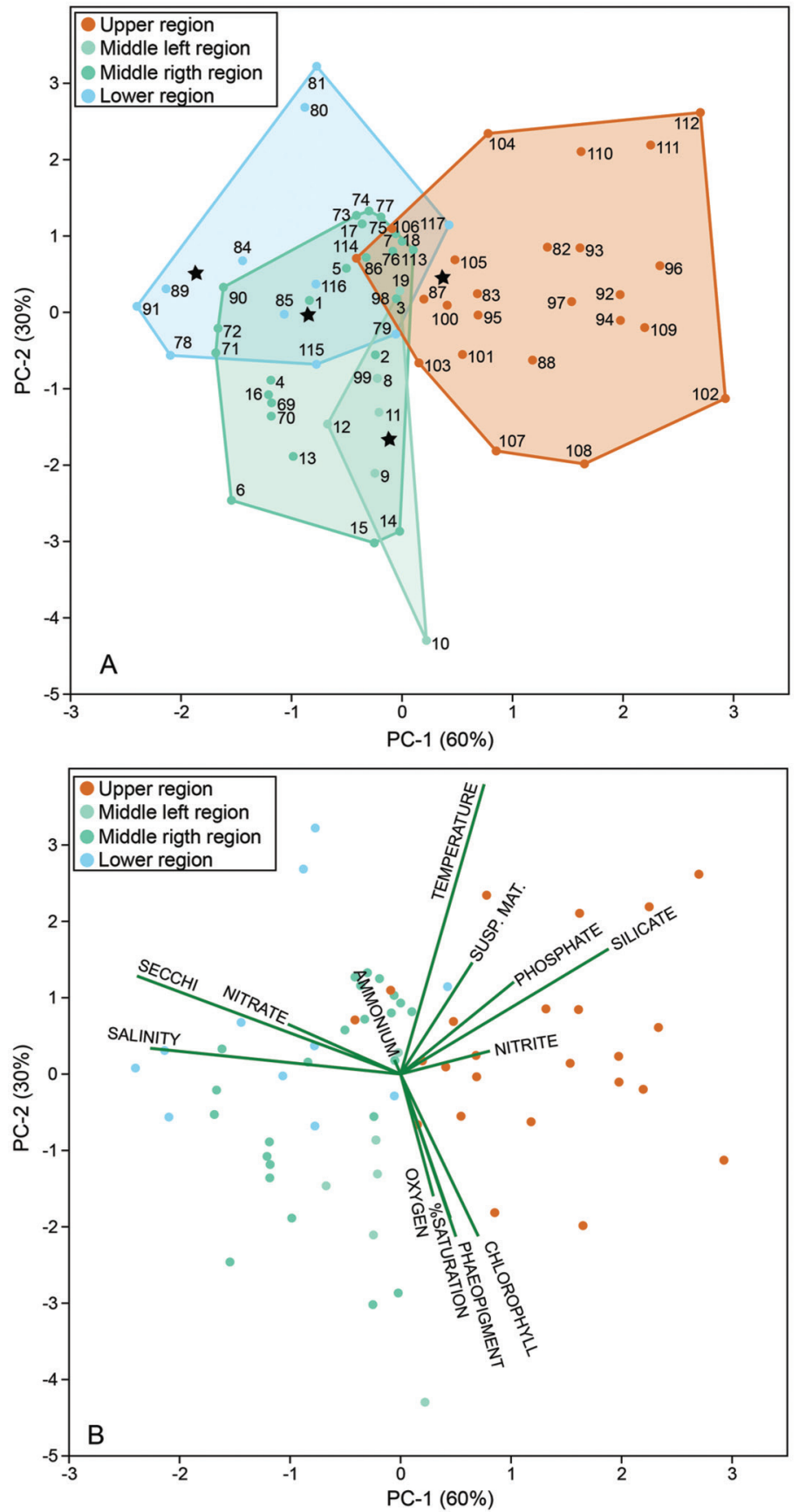

Fig. 3. Gulf of Nicoya estuary: Between Groups Principal Component Analysis (PCA) performed on 13 parameters (Secchi depth, salinity, temperature, dissolved oxygen, oxygen saturation, suspended matter, chlorophyll- $a$, phaeopigments, phosphate, silicate, ammonium, nitrite, and nitrate) at 68 surface (1 m depth) water stations at four regions (Upper, middleleft, middle-right, lower) of the Gulf, Pacific coast of Costa Rica (Fig. 1B), 2000-2002. A. Separation of the four-region groups of stations. The PCA centroid for each group is indicated by a star. Each polygon includes all stations (listed in Table 1) of a region. B. PCA biplot. Vectors indicating relative importance of parameters are represented by radiating lines. 
TABLE 4

Gulf of Nicoya estuary: Results of the Mann-Whitney $\mathrm{U}$ test comparison of medians of stations sampled during the dry and rainy seasons in the Upper and Middle Gulf regions. Pacific coast of Costa Rica 2000-2002

\begin{tabular}{|c|c|c|c|c|c|c|c|}
\hline Parameter & Season & $\mathrm{N}$ & Min & $\operatorname{Max}$ & Median & $\mathrm{U}$ test & $\mathrm{p}$ \\
\hline \multirow[t]{2}{*}{ Secchi } & Dry & 25 & 0.4 & 2 & 1 & 280.50 & 0.7013 \\
\hline & Rainy & 24 & 0.1 & 1.5 & 1 & & \\
\hline \multirow[t]{2}{*}{ Salinity } & Dry & 25 & 22 & 32 & 27 & 157.50 & 0.004 \\
\hline & Rainy & 24 & 13 & 31 & 24 & & \\
\hline \multirow[t]{2}{*}{ Temperature } & Dry & 25 & 26.6 & 31 & 28.5 & 215.00 & 0.089 \\
\hline & Rainy & 24 & 28 & 31.1 & 29.05 & & \\
\hline \multirow[t]{2}{*}{ Oxygen } & Dry & 25 & 5.2 & 11.4 & 7.18 & 93.50 & $<0.001$ \\
\hline & Rainy & 24 & 3.6 & 7.8 & 5.27 & & \\
\hline \multirow[t]{2}{*}{$\% \mathrm{O}_{2}$ sat. } & Dry & 25 & 87.4 & 188.3 & 118 & 92.50 & $<0.001$ \\
\hline & Rainy & 24 & 55.8 & 131 & 89.5 & & \\
\hline \multirow[t]{2}{*}{ Susp. matter } & Dry & 22 & 10.33 & 68.22 & 19.32 & 196.00 & 0.138 \\
\hline & Rainy & 24 & 9.52 & 107.89 & 27.89 & & \\
\hline \multirow{2}{*}{ Chlorophyll- $a$ I } & Dry & 25 & 0.78 & 16.21 & 5.59 & 283.00 & 0.741 \\
\hline & Rainy & 24 & 3.03 & 15.55 & 5.49 & & \\
\hline \multirow[t]{2}{*}{ Phaeopigm. } & Dry & 25 & 0 & 5.77 & 1.29 & 240.00 & 0.234 \\
\hline & Rainy & 24 & 0.43 & 6.37 & 1.485 & & \\
\hline \multirow[t]{2}{*}{$\mathrm{PO}_{4}^{3-}$} & Dry & 25 & 0.28 & 1.82 & 0.78 & 126.50 & $<0.001$ \\
\hline & Rainy & 24 & 0.44 & 9.53 & 1.29 & & \\
\hline \multirow[t]{2}{*}{$\mathrm{SiO}(\mathrm{OH})_{3}^{-}$} & Dry & 25 & 0.18 & 63.64 & 4.42 & 114.00 & $<0.001$ \\
\hline & Rainy & 24 & 3.93 & 107.79 & 34.06 & & \\
\hline \multirow[t]{2}{*}{$\mathrm{NH}_{4}^{+}$} & Dry & 25 & 0.03 & 2.66 & 0.5 & 225.00 & 0.134 \\
\hline & Rainy & 24 & 0.17 & 1.45 & 0.71 & & \\
\hline \multirow[t]{2}{*}{$\mathrm{NO}_{3}^{-}$} & Dry & 25 & 0.06 & 3.59 & 0.4 & 224.50 & 0.133 \\
\hline & Rainy & 24 & 0.03 & 4.59 & 0.72 & & \\
\hline \multirow[t]{2}{*}{$\mathrm{NO}_{2}^{-}$} & Dry & 25 & 0 & 0.51 & 0.08 & 132.50 & $<0.001$ \\
\hline & Rainy & 24 & 0 & 2.47 & 0.56 & & \\
\hline
\end{tabular}

T. River mouth: dry $(88,101,109)$, rainy $(94,97,112)$ W. Chira Island: dry $(87,103,105,108)$, rainy $(82,93$, $96,111)$ Cortezas islands: dry $(04,05,06,13,14,15,16$, $69,71,72,90,99)$, rainy $(01,02,03,07,17,18,73,76,77$, 95, 113, 114) Caballo Island: dry $(08,10,12)$, rainy (19) Jicaral: dry $(86,104,107)$, rainy $(92,110,95)$. Total dry $=25$. Total rainy $=24$.

similar to the Middle right region $(p=0.105)$, but it differed from the rest $(\mathrm{p}<0.005)$. Both Middle regions were similar $(\mathrm{p}>0.281)$, but only the left region was similar to the Upper region $(p=0.080)$.

C. Primary productivity: Results of the depth-integrated Net Primary Productivity estimates at the four embayments are included in
Table 5. Net productivity varied within and between days. Oxygen consumption was greater than production (negative in Table 5) ) at several dates and times in Culebra Bay, Golfito Bay and Moin Bay (Table 5, A, C, D). Oxygen production was positive for all dates in the Gulf of Nicoya (Table 5B). However, the maximum net primary productivity estimate for the four embayments was $6.044 \mathrm{~g} \mathrm{C} / \mathrm{m}^{2} /$ day (2 $206 \mathrm{~g} \mathrm{C} / \mathrm{m}^{2} /$ year) from Culebra Bay on June 29, 2000 (Table 5A). This highest productivity estimate was preceeded by $1218 \mathrm{~g} \mathrm{C} / \mathrm{m}^{2} /$ year at the site during the afternoon of the previous day, and a negative production in the morning of the same day. The lowest net primary production was recorded at Moín Bay on October 5, 2000 (30 g C/m²/year).

Results of the Spearman rho rank correlation test between net primary productivity $(\mathrm{g} \mathrm{C} /$ $\mathrm{m}^{2} /$ day) and the environmental parameters are included in Table 5 E. Only temperature and silicate had $p$ values below 0.05 .

\section{DISCUSSION}

Our initial hypothesis was that the four coastal embayments were different enough in their area, depth, tidal amplitude, exposure, rainfall, and morphology, so they could be clearly separated from each other based on the data set. Although the results of the PCA test confirmed that the four sites could be separated based on the 13 parameters, they had several overlapping stations. This latter result points out to the need of deploying as many stations as possible to account for spatial and temporal variability. This is important if future studies dealing with within-site and betweensites comparisons are conducted aimed at the identification of trends at different scales, like eutrophication and climate change.

The four embayments sampled during the 2000-2002 are under the influence of seasonal rainfall. This seasonality is a key factor on the estuarine dynamics of the Gulf of Nicoya. Seasonal rainfall is also important in Golfito and Moín bays, and less so in Culebra Bay, where upwelling events may be more important. The key role played by rainfall as a source of 
TABLE 5

The four embayments: Estimates of Net Primary Productivity (grams of Carbon / unit area / unit time) by the light vs dark BOD bottle oxygen change method at: A. Gulf of Nicoya, B. Golfito Bay, C. Culebra Bay, D. Moín Bay. E. Spearman rho rank correlation between Net PP / day and 13 parameters. 2000-2002. Costa Rica

\begin{tabular}{|c|c|c|c|c|c|c|c|c|c|c|c|c|c|}
\hline \multicolumn{3}{|c|}{ Locality } & Date & \multicolumn{2}{|c|}{ Incubation } & \multirow[t]{2}{*}{ Secchi } & \multirow[t]{2}{*}{$\mathrm{T}^{\circ} \mathrm{C}$} & \multicolumn{2}{|l|}{ Chlorophyll- $a$} & \multirow[t]{2}{*}{$\mathrm{SiO}(\mathrm{OH})_{3}^{-}$} & \multirow[t]{2}{*}{$\begin{array}{c}\text { Net } \\
\text { PP / day }\end{array}$} & \multicolumn{2}{|c|}{$\begin{array}{c}\text { Net } \\
\text { PP / year }\end{array}$} \\
\hline \multicolumn{10}{|c|}{$\mathbf{A}$} & & & & \\
\hline \multicolumn{3}{|c|}{ Cortezas islands } & Mar. 22-00 & $14: 30$ & $-17: 30$ & 1.5 & 28.2 & 16.2 & & 0.26 & 4.381 & & 601 \\
\hline \multicolumn{3}{|c|}{ Cortezas islands } & Apr. 12-00 & $11: 20$ & $-14: 15$ & 2.0 & 28.6 & 5.59 & & 0.18 & 3.261 & & 190 \\
\hline \multicolumn{3}{|c|}{ Cortezas islands } & Apr. 12-00 & $11: 55$ & $-14: 15$ & 0.8 & 27.7 & 5.66 & & 0.18 & 2.658 & & 70 \\
\hline \multicolumn{3}{|c|}{ Puntarenas } & Apr. 11-00 & $11: 40$ & $-14: 00$ & 2.0 & 28.0 & 5.00 & & 0.18 & 1.597 & & 83 \\
\hline \multicolumn{3}{|c|}{ Cortezas islands } & Sep. 01-00 & $11: 45$ & $-14: 05$ & 1.1 & 29.0 & 6.51 & & 35.18 & 1.673 & & 11 \\
\hline \multicolumn{3}{|c|}{ Caballo Island } & Sep. 01-00 & $11: 20$ & $-13: 50$ & 1.0 & 28.0 & 9.02 & & 36.52 & 1.298 & & 74 \\
\hline \multicolumn{3}{|c|}{ Puntarenas } & Aug. 31-00 & $12: 03$ & $-14: 30$ & 1.0 & 28.0 & 4.79 & & 15.87 & 0.524 & & 91 \\
\hline \multicolumn{3}{|c|}{ Cortezas islands } & Apr. 06-01 & $09: 40$ & $-12: 40$ & 1.5 & 28.0 & 5.23 & & 0.99 & 2.047 & & 47 \\
\hline \multicolumn{3}{|c|}{ Caballo Island } & Apr. 05-01 & $08: 55$ & $-12: 00$ & 1.0 & 28.2 & 7.13 & & 0.99 & 0.953 & & 48 \\
\hline \multicolumn{3}{|c|}{ Puntarenas } & Apr. 04-01 & 09:00 & $-12: 00$ & 2.0 & 27.8 & 3.35 & & 0.99 & 1.253 & & 57 \\
\hline \multicolumn{14}{|c|}{ B } \\
\hline \multicolumn{3}{|c|}{ Golfito islet } & May 10-00 & $09: 22$ & $-12: 00$ & 2.8 & 29.6 & 0.65 & & 6.91 & Negative & Neg & gative \\
\hline Golfito & Cacao & & May 10-00 & 11:00 & $-13: 30$ & 2.5 & 29.5 & 1.69 & & 8.63 & 0.187 & & 68 \\
\hline Golfito & channe & & May 10-00 & $13: 00$ & $-15: 20$ & 2.2 & 29.5 & 1.71 & & 6.49 & 1.905 & & 95 \\
\hline Golfito & islet & & Nov. 24-00 & $11: 53$ & $-14: 18$ & 2.2 & 29.0 & 1.51 & & 32.11 & 1.189 & & 34 \\
\hline Golfito & Cacao & & Nov. 23-00 & $11: 37$ & $14: 00$ & 4.0 & 28.5 & 0.86 & & 11.23 & 0.171 & & 62 \\
\hline Golfito & channe & & Nov. 22-00 & $12: 26$ & $-15: 00$ & 4.0 & 29.0 & 0.63 & & 21.57 & 3.757 & & 371 \\
\hline Golfito & islet & & Feb. 07-02 & 09:22 & $-11: 42$ & 2.3 & 32.0 & 0.93 & & 14.62 & Negative & Neg & gative \\
\hline & $\mathbf{C}$ & & & & & & & & & & & & \\
\hline Culebra & Panam & & Jun. 28-00 & $11: 10$ & $-13: 30$ & 12.6 & 29.0 & 0.36 & & 0.36 & Negative & Nege & rative \\
\hline Culebra & Nacas & colo & Jun. 28-00 & $13: 00$ & $-15: 40$ & 10.0 & 29.3 & 0.55 & & 0.36 & 3.337 & & 218 \\
\hline Culebra & Esmer & alda & Jun. 29-00 & $08: 42$ & $-11: 42$ & 9.0 & 28.0 & 0.48 & & 0.36 & 6.044 & & 206 \\
\hline Culebra & Panam & & Oct. $19-00$ & 08:00 & $-11: 00$ & 4.5 & 28.5 & 2.23 & & 4.37 & Negative & Neg & rative \\
\hline Culebra & Nacas & colo & Oct. $18-00$ & $12: 00$ & $-14: 20$ & 4.2 & 28.5 & 1.61 & & 0.78 & 0.330 & & 20 \\
\hline Culebra & Esmer & alda & Oct. 19-00 & $08: 37$ & $-11: 38$ & 7.0 & 27.0 & 1.51 & & 0.58 & 2.884 & & 053 \\
\hline Culebra & Esmer & alda & May. 24-01 & $09: 12$ & $-12: 12$ & 10.0 & 29.0 & 0.36 & & 0.99 & 2.203 & & 04 \\
\hline & D & & & & & & & & & & & & \\
\hline Moín pc & & & May. 25-00 & $12: 25$ & $-14: 45$ & 3.3 & 29.0 & 0.21 & & 0.79 & 1.227 & & 48 \\
\hline Moín R & ed buoy & & May. 25-00 & $12: 02$ & $-14: 16$ & 5.0 & 29.5 & 0.20 & & 0.79 & Negative & Neg & gative \\
\hline Moín G & Ireen bu & & May. 25-00 & $10: 50$ & $13: 10$ & 6.0 & 29.5 & 0.15 & & 0.79 & 0.455 & & 66 \\
\hline Moín p & & & Oct. $05-00$ & $12: 00$ & $14: 28$ & 3.0 & 29.5 & 1.52 & & 0.79 & 3.015 & & 100 \\
\hline Moín G & Ireen bu & 1oy & Oct. $05-00$ & $08: 40$ & $11: 10$ & 4.1 & 30.0 & 1.41 & & 5.86 & 0.081 & & 30 \\
\hline Moín R & ed buoy & & May. 10-01 & $09: 25$ & $12: 25$ & 6.5 & 29.0 & 0.58 & & 26.13 & Negative & Neg & gative \\
\hline Moín p & & & May. 10-01 & $11: 45$ & $15: 00$ & 3.0 & 30.0 & 0.59 & & 29.23 & Negative & Neg & gative \\
\hline & $\mathbf{E}$ & & & & & & & & & & & & \\
\hline $\begin{array}{c}\text { Net } \\
\mathrm{PP} / \text { day }\end{array}$ & $\begin{array}{c}\text { Secchi } \\
\text { dept }\end{array}$ & Salinity & $\mathrm{O}_{2}$ & \% Sat. & Susp. Matt. & t. $\mathrm{Chl}$ & rophyll & Phaeopigmets & $\mathrm{PO}_{4}^{3-}$ & $\mathrm{SiO}(\mathrm{OH})_{3}^{-}$ & $\mathrm{NH}_{4}^{+}$ & $\mathrm{NO}_{2}^{-}$ & $\mathrm{NO}_{3}^{-}$ \\
\hline rs & -0.10 & -0.04 & $\begin{array}{ll}-0.44 & -0.07\end{array}$ & -0.12 & 0.04 & & .21 & 0.35 & 0.31 & -0.41 & 0.10 & 0.02 & 0.28 \\
\hline$p$ & 0.585 & 0.850 & $\begin{array}{ll}\mathbf{0 . 0 1 3} & 0.702 \\
\end{array}$ & 0.508 & 0.820 & & 254 & 0.057 & 0.094 & 0.022 & 0.578 & 0.905 & 0.131 \\
\hline
\end{tabular}

Locality. Date (Month-Day-Year), Incubation time interval, Secchi depth (m), Chlorophyll- $a\left(\mathrm{mg} / \mathrm{m}^{3}\right)$, Silicate $(\mu \mathrm{mol} / \mathrm{L})$, Net PP / day $\left(\mathrm{gC} / \mathrm{m}^{2} /\right.$ day), Net PP / year $\left(\mathrm{gC} / \mathrm{m}^{2} /\right.$ year). Negative = oxygen consumption greater than production. 
nutrients via runoff to temperate estuaries has been emphasized by Mallin, Pearl, Rudek, \& Bates (1993). They also point out that changes in global or local weather patterns influencing rainfall are likely to have a significant impact in estuarine nutrient dynamics and productivity.

Culebra Bay was the site with the clearest water of the four embayments (Secchi depth: $12.6 \mathrm{~m}$ ) and the temperature had the widest range $\left(24.0\right.$ to $\left.32.5^{\circ} \mathrm{C}\right)$. It was also a bay with low values for suspended matter $(4.12 \mathrm{mg} / \mathrm{L})$, and non detected phaeopigments and nitrite. Maximum chlorophyll- $a$ concentration was the lowest $\left(2.23 \mathrm{mg} / \mathrm{m}^{3}\right)$ of the four embayments. In a year study (2004-2005), Fernández-García, Cortés, Alvarado, \& Nivia-Ruiz (2012) reported maximum / minimum values (Units as in Table 2) of: temperature $(29.6 / 22.9)$, salinity $(34.3$ / 30.0), chlorophyll- $a$ (3.8 / 0.4), suspended sediments (10.2 / 3.3), phosphate (1.45 / 0.03), silicate (5.88 / non detected), nitrite (1.18 / non detected), nitrate (15.60/ non detected), and ammonium (0.52 / non detected). These parameters make Culebra Bay waters characteristic of open ocean conditions. However, cooling conditions occcur from time to time (Alfaro \& Cortés, 2012; Rixen, Jiménez, \& Cortés, 2012; Rodríguez-Sáenz \& Morales-Ramírez, 2012) Water warming related to El Niño Southern Oscillation (ENSO) is also important in the region and has been the cause of coral bleaching and mortality at Culebra Bay (Jiménez, Cortés, León, \& Ruiz, 2001).

The information on water characteristics of the Gulf of Nicoya comes mainly from cruises aboard the RV Skimmer in the early 1980's (Vargas, 2016). The reports by Voorhis, Epifanio, Maurer, Dittel, \& Vargas (1983) and Epifanio, Maurer, \& Dittel (1983) clearly identified the estuarine nature of the embayment. The influence of seasonal (May to November) freshwater input due to rains falling directly on the estuary, or carried there mainly by the Tempisque river as runoff from its extensive watershed, has been emphasized by Vargas \& Mata (2004) and Vargas (2016). The results of this study confirm the seasonality of certain water parameters in the estuary. Higher salinities are expected during the dry season and lower values during the rainy season. Moreover, the influx of certain nutrients, like phosphate and silicate, during the rainy season were also expected. On the other hand, during the dry season (December to April) the estuary is under the influence of Easterly winds that increase water mixing. Thus, higher values for dissolved oxygen and percent saturation were expected during the dry season. Epifanio et al. (1983) found that, with the exception of phosphate, concentrations of ammonium, nitrite and nitrate varied seasonally. During 2000-2001, Palter, León-Coto, \& Ballestero (2007) collected data on dissolved oxygen, nutrients and chlorophyll- $a$ in the Gulf of Nicoya. They found that nutrients were more concentrated in the upper Gulf during the rainy season and concluded that the Tempisque River controls spatial and temporal variability of nutrients in the upper Gulf. The maximum values found by Palter et al. (2007) in the Gulf (Stations taken along the estuary at a depth range of 0 to $35 \mathrm{~m}$ (Units as in this study), were: Dry / Rainy seasons (Secchi depth: 0.4 / ND; Temperature: 28.4 / 29.9; Salinity 29.2 / 26.9; Percentage of oxygen saturation: 130 / 131; Chlorophyll-a 3.3 / 12.63; Phosphate 1.75 / 3.35; Silicate 127.7 / 165.3: Nitrite 0.77 / 1.71; Nitrate 9.10 / 10.27. With the exception of higher phosphate (9.50) and lower nitrate (4.59) found in our study, the values found in their survey for other parameters are similar to those found in our study.

The estuarine nature of Golfo Dulce, where Golfito Bay is located, has been studied by Svendsen et al. (2006). However, Golfo Dulce differs from the Gulf of Nicoya on its deep bathymetry $(200 \mathrm{~m})$ and the presence of a sill $(60 \mathrm{~m})$ at the entrance, which makes Golfo Dulce similar to an European fjord. This similarity has encouraged comparative research leading to significant discoveries, such as the anammox reaction (Dalsgaard, Canfield, Petersen, Thamdrup, \& AcuñaGonzález, 2003). In contrast with Golfo Dulce, Golfito Bay is a small shallow semi-enclosed embayment connected to Golfo Dulce by a tidal channel. Comparative data on dissolved oxygen and nutrient profiles for Golfito bay is available 
from a 1998 survey near the mouth of a creek that flows near the Northeastern end of the Bay (Silva \& Acuña-González, 2006). They found maximum values (Units as in this study) of: Secchi depth (2.0), salinity (33), temperature (33.0), suspended matter (96.0). Maximum nutrient concentrations, were: nitrate (13.52), nitrite (0.88), phosphate (0.86), and silicate (110.4). Maximum chlorophyll- $a$ concentration was 7.9 $\mathrm{mg} / \mathrm{L}$. The data reported by Silva \& AcuñaGonzález (2006) is similar to data found during our 2000-2002 study, except for a lower maximum concentration (1.33) of nitrate. Moreover, suspended matter in Golfito Bay had the highest concentration $(156.04 \mathrm{mg} / \mathrm{L})$ of the four embayments. The Golfito Bay region is under the influence of heavy rains during most of the year and runoff flows directly into the bay. This runoff carries nutrients and suspended matter from the nearby rain forest, the mangrove forest, and also brings into the bay loads of untreated sewage and other pollutants from the city and port activities (Spongberg \& Davis, 1998; García et al., 2006).

Moín port is within a bay exposed to the Caribbean Sea. The Moín River carries sediments and nutrients from mangrove forests and agricultural lands. The estuary also houses a fluvial port and an oil refinery further upstream (Acuña-González et al., 2004). Data on nutrients from the Caribbean coast comes mainly from a 1997 survey by Muller-Parker \& Cortés (2001). They found minimum-maximum concentrations $(\mu \mathrm{mol} / \mathrm{L})$ of: phosphate $(0.06$ to 0.54 ), ammonium (0.3 to 15.4$)$, nitrite (0.01 to 0.13 ) and nitrate ( 0.20 to 3.56$)$. Minimummaximum concentrations $(\mu \mathrm{mol} / \mathrm{l})$ found at Moín Bay in our 2000-2002 survey, were: phosphate (0.02 to 2.91), ammonium (0.07 to $2.24 \mu \mathrm{mol} / \mathrm{L})$, nitrite $(0.00$ to $0.40 \mu \mathrm{mol} / \mathrm{L})$, nitrate $(0.01$ to 1.63$)$. Their results are within the range of those reported in this study. These relatively low values are similar to those found in Culebra Bay. Both Culebra and Moin bays are under the direct influence of Pacific and Caribbean conditions, respectively.

In this study we followed the definition of Cloern, Foster, \& Klechner (2014) of productivity as the rate of production per unit time. Based on early reports like Riley \& Chester (1971), our hypothesis was that higher productivity was to be expected in estuarine embayments like the Gulf of Nicoya and Golfito Bay, and lower values in near open-ocean conditions, such as Culebra and Moin bays. However, the highest net primary productivity (2 $206 \mathrm{~g} \mathrm{C} / \mathrm{m}^{2} /$ year) found in this study was mesusred in Culebra Bay. This value followed lower and negative productions during the afternoon and morning of the previous day, respectively. This high variability may be indicative of patchy environmental conditions acting within hourly and daily time frames. Red tide outbreaks have been observed occasionally in Culebra Bay (Morales-Ramírez, Víquez, Rodríguez, \& Vargas, 2001), but no patches were observed during our survey.

Primary productivity estimates using the same methods (Oxygen change after incubation) as in this study have been conducted in the Gulf of Nicoya by Córdoba-Muñoz (1998) and Gocke, Cortés, \& Murillo (2001a). Both studies were performed near the Cocorocas islands. Córdoba-Muñoz (1998) found a maximum value of $1.81 \mathrm{~g} \mathrm{C} / \mathrm{m}^{2} /$ day $\left(662 \mathrm{~g} \mathrm{C} / \mathrm{m}^{2} /\right.$ year), while Gocke et al. (2001a) reported maximum net primary production of $2.76 \mathrm{~g} \mathrm{C} /$ $\mathrm{m}^{2} /$ day (1 $007 \mathrm{~g} \mathrm{C} / \mathrm{m}^{2} /$ year) at a mangrove tidal channel, and higher net PP values were influenced by red tides. Red tides have been reported frequently on the Gulf of Nicoya (Viquez \& Hargraves, 1995) but no patches were observed during our 2000-2002 survey. Net primary productivity estimates in the Gulf of Nicoya estuary found during this study had all values as positive, with a maximum of $1601 \mathrm{~g} \mathrm{C} / \mathrm{m}^{2} /$ year and a minimum of $191 \mathrm{~g} \mathrm{C} / \mathrm{m}^{2} /$ year. These estimates of net PP are similar to those previously reported for the Gulf of Nicoya.

Net primary productivity in Golfito Bay and Moín Bay had maximum values of 1371 and $1100 \mathrm{~g} \mathrm{C} / \mathrm{m}^{2} /$ year, respectively. These values are similar to those found in the other two embayments.

If the above mentioned maximum values of Net Primary Production (Net PP) found at 
the four embayments are considered as representing unusual conditions and therefore are excluded when computing the average values, the following trend of decreasing estimates of Net PP (g C/m²/year) emerges: Gulf of Nicoya (619) > Culebra Bay (456) > Golfito Bay (180) $>$ Moín Bay (92), which fits into the general acceptance of estuaries and upwelling regions as highly productive ecosystems. Moín Bay is close to low productivity tropical ocean conditions. Golfito Bay is a special case due to its small area, restricted circulation, and the impact of urban and forest runoffs.

It has been argued that primary production in coastal areas may be nutrient-limited (particularly nitrogen and phosphorus) mainly in temperate estuaries (Epifanio, Maurer, \& Dittel (1983). However, information is scarce for tropical ecosystems. This problem is becoming more relevant in the context of eutrophication of coastal ecosystems and climatic change (Chávez, Messie, \& Pennington, 2011). The recent review by Cloern, Foster, \& Kleckner (2014) found a range from negative to 1890 g C $/ \mathrm{m}^{2} /$ year in 1148 estimates of primary production in estuarine systems (including the Gulf of Nicoya). They pointed out that PP may vary up to ten fold within ecosystems. Based on their figure of $500 \mathrm{~g} \mathrm{C} / \mathrm{m}^{2} /$ year separating eutrophic from hypertrophic conditions, estuaries like the Gulf of Nicoya may reach eutrophication frequently (mean $619 \mathrm{~g} \mathrm{C} / \mathrm{m}^{2} /$ year) or become hypertrophic at times. Future studies may provide information to evaluate this trend towards hypertrophic conditions.

Primary productivity estimates are based on the relationship between oxygen produced and carbon fixed thru the photosynthetic quotient (PQ). In this study we used a value of PQ of 1.2. However, PQ may vary from 1.0 to 1.4 (Cloern et al., 2014). Estimates of primary productivity, based on the change of dissolved oxygen concentration (determined by the modified micro Winkler method) after a period of incubation of a water sample, have been reported for decades worldwide. However, the results must be viewed with caution when the method is employed either in oligotrophic waters, or in waters with high bacterial counts (Riley \& Chester, 1971). In our study, oligotrophic conditions were expected in Moín Bay year around, and in Culebra Bay during nonupwelling periods. During the 2000 survey Culebra Bay was found the least polluted (coliform bacterial counts) of the four embayments, while Golfito Bay had the highest bacterial counts (García et al., 2006). Moreover, the role of phytoplankton in net primary productivity is crucial. However, phytoplankton in general has a patchy distribution in space and time. Thus, which type and how many microalgal cells are finally incubated in net PP estimates is a guess, and no correlation of net PP with chlorophyll- $a$ is frequently found, as in this study. To what extent the results of the net PP estimates for the four embayments were influenced by the above mentioned factors is unknown.

Of the 1148 estimates of Annual Phytoplankton Primary Productivity (APPP) compiled by Cloern et al. (2014) only 15 were from the South and Central Americas, and included only one report (Gocke, Cortés, \& Murillo, 2001b) from Costa Rica (Gulf of Nicoya). Thus, the need for future estimates of net primary productivity as APPP is growing to facilitate comparisons with other environments worldwide, and to assess trends of productivity influenced by coastal development, pollution, and global climate change. Data included in this study are a key reference for the Central American region.

\section{ACKNOWLEDGMENTS}

The collection and analyzes of samples was made possible by grants from the Costa Rica-United States of America Foundation for Cooperation (CR-USA), and the University of Costa Rica (UCR) Project 808-AO-506. We thank Davis Morera and Eleazar Ruiz for their help in the field and the laboratory.

\section{RESUMEN}

Parámetros del agua y productividad primaria en cuatro bahías marinas de Costa Rica (2000-2002). La 
disponibilidad de datos sobre parámetros acuáticos y productividad primaria es esencial en estudios comparativos orientados a la identificación de tendencias ambientales, como la eutroficación, en ambientes costeros. En este contexto, el objetivo de este trabajo es hacer accesible datos, colectados entre el 2000 y 2002, de 13 parámetros acuáticos (Profundidad de Secchi, temperatura, salinidad, oxígeno disuelto, saturación de oxigeno, material suspendido, clorofila- $a$, faeopigmentos, fosfato, silicato, amonio, nitrito y nitrato) su variación temporal y distribución espacial, y productividad primaria, en cuatro sitios costeros de Costa Rica. El estudio multi-paramétrico fue realizado con base en muestras superficiales (1 m profundidad) de agua recolectadas en 128 estaciones en tres bahías costeras en la costa del Pacífico y una en la del Caribe de Costa Rica: una bahía (Bahía Culebra) bajo la influencia de afloramiento costero, un estuario de marea (Golfo de Nicoya), una pequeña bahía semi-cerrada rodeada de manglares (Bahía de Golfito), y una bahía y puerto del Caribe (Bahía Moín). Mediante Análisis de Componentes Principales (PCA) se obtuvo una distribución grafica de las estaciones de los cuatro sitios en general y para el Golfo de Nicoya en particular. PCA Gabriel biplots fueron utilizados para ilustrar la importancia relativa de cada parámetro en la separación de las estuaciones. Los cuatro ambientes fueron separados por el PCA con base en los 13 parámetros. Los valores máximos encontrados fueron: Secchi: $12.6 \mathrm{~m}$; salinidad: $35 \mathrm{psu}$, temperatura: $32.5^{\circ} \mathrm{C}$, oxígeno disuelto: $11.4 \mathrm{mg} / \mathrm{L}$; porcentaje de saturación de oxígeno disuelto: $188 \%$; material suspendido: $156.04 \mathrm{mg} / \mathrm{L}$; clorofila- $a$ : $16.21 \mathrm{mg} / \mathrm{m}^{3}$; faeopigmentos: $6.37 \mathrm{mg} / \mathrm{m}^{3}$; fosfato: $9.53 \mu \mathrm{mol} / \mathrm{L}$; silicato: $156.11 \mu \mathrm{mol} / \mathrm{L}$; amonio: $2.66 \mu \mathrm{mol} / \mathrm{L}$; nitrito: $2.47 \mu \mathrm{mol} / \mathrm{L}$ y nitrato: $4.59 \mu \mathrm{mol} / \mathrm{L}$. La salinidad y algunos nutrimentos variaron estacionalmente (seca $v s$ lluviosa) en el estuario del Golfo de Nicoya. Estimaciones de la productividad primaria neta (P.P. neta, método de oxígeno de Winkler) produjo un máximo de $2206 \mathrm{~g} \mathrm{C} / \mathrm{m}^{2} /$ año en Bahía Culebra.

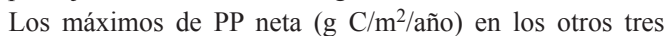
sitios, fueron: 1601 (Golfo de Nicoya), 1371 (Bahía de Golfito), y1 100 (Bahía Moín). Los valores de PP neta mostraron una alta variabilidad espacial y temporal, y oscilaron desde negativos hasta aquellos asociados a condiciones oligotróficas, eutróficas e hipertróficas. En el Golfo de Nicoya $60 \%$ de los valores de PP neta excedieron el valor de referencia ( $500 \mathrm{~g} \mathrm{C} / \mathrm{m}^{2} / \mathrm{año}$ ) para separar condiciones eutróficas de las hipertróficas.

Palabras clave: nutrientes, clorofila-a, eutrofización, estuario, afloramiento, Pacífico Este, Caribe.

\section{REFERENCES}

Anderson, M. J. (2001). A new method for non-parametric multivariate analysis of variance. Austral Ecology, 26, 32-46.
Acuña-González, J., Vargas-Zamora, J. A., Gómez-Ramírez, E., \& García-Céspedes, J. (2004). Hidrocarburos de petróleo, disueltos y dispersos, en cuatro ambientes costeros de Costa Rica. Revista de Biología Tropical, 52(Supl. 2), S43-S50.

Alfaro, E. J., \& Cortés, J. (2012). Atmospheric forcing and cool subsurface water events in Bahia Culebra, Gulf of Papagayo, Costa Rica, Revista de Biologia Tropical, 60(Suppl. 2), S173-S186.

Chávez, F., Messie, M., \& Pennington, J.T. (2011). Marine Primary Production in relation to climate variability and change. Annual Review of Marine Science, 3, 227-260.

Cheek, A.O. (2006). Subtle sabotage, endocrine disruption in wild populations. Revista de Biología Tropical, 54(Suppl. 1), S1-S19.

Cloern, J.E., Foster, S.O., \& Klechner, A. E. (2014). Phytoplankton primary production in the worlds's estuarine-coastal ecosystems. Biogeosciences, 11, 2477-2501.

Conover, W.J. (1971). Practical non-parametric statistics. New York, USA: John Wiley \& Sons, Inc.

Córdoba-Muñoz, R. (1998). Primary productivity in the water column of Estero Morales, a mangrove system in the Gulf of Nicoya, Costa Rica. Revista de Biología Tropical, 46(Suppl. 6), S257-S262.

Dalsgaard, T., Canfield, D.E. Petersen, J. Thamdrup, B., \& Acuña-González, J. (2003). $\mathrm{N}_{2}$ production by the anammox reaction in the anoxic water column of Golfo Dulce, Costa Rica. Nature, 422, 606-608.

Dean, H. K. (2004). Marine biodiversity of Costa Rica; Class Polychaeta (Annelida). Revista de Biología Tropical, 52(Suppl. 2), S131-S204.

Dean, H. K. (2008). The use of polychaetes (Annelida) as indicator species of marine pollution, a review. Revista de Biología Tropical, 56(Suppl. 4), S11-S38.

Dean, H. K. (2009). Polychaetes and echiurans. In I. S. Wehrtmann, \& J. Cortés (Eds.). Marine Biodiversity of Costa Rica, Central America (pp. Text: 181-191, Species List: Compact Disc pp. 122-159). Berlin: Springer + Business Media B.V.

Dolédec, S., \& Chessel, D. (1991). Recent developments in linear ordination methods for environmental sciences. Advances in Ecology, India, 1, 133-155.

Epifanio, C. E., Maurer, D., \& Dittel, A. I. (1983). Seasonal changes in nutrients and dissolved oxygen in the Gulf of Nicoya, a tropical estuary on the Pacific coast of Central America. Hydrobiologia, 101, 231-238.

Fernández-García, C., Cortés, J., Alvarado, J. J., \& Nivia-Ruiz, J. (2012). Physical factors contributing to the benthic dominance of the algae Caulerpa 
sertularioides (Caulerpaceae, Chlorophyta) in the upwelling Bahía Culebra, north Pacific of Costa Rica. Revista de Biología Tropical, 60(Suppl. 2), S93-S107.

García, V., Acuña-González, J., Vargas-Zamora, J. A., \& García-Céspedes, J. (2006). Calidad bacteriológica y desechos sólidos en cinco ambientes costeros de Costa Rica. Revista de Biología Tropical, 54(Supl. 1), S35-S48.

García-Céspedes, J., Acuña-González, J. A., \& VargasZamora, J. A. (2004). Metales traza en sedimentos de cuatro ambientes costeros de Costa Rica. Revista de Biología Tropical, 52(Supl. 2), S51-S60.

Gocke, K., Cortés, J., \& Murillo, M. M. (2001a). Planktonic primary production in a tidally influenced mangrove forest on the Pacific coast of Costa Rica. Revista de Biología Tropical, 49(Suppl. 2), S279-S288.

Gocke, K., Cortés, J., \& Murillo, M.M. (2001b). The annual cycle of primary productivity in a tropical estuary, The inner regions of the Golfo de Nicoya, Costa Rica. Revista de Biología Tropical, 49(Suppl. 2), S289-S306.

Gocke, K., Cortés, J., \& Villalobos, C. (1990). Effects of red tides on oxygen concentration and distribution in the Gulf of Nicoya, Costa Rica. Revista de Biología Tropical, 38, 401-407.

Gravel, P., Johanning, K., McLachlan, J., Vargas, J.A., \& Oberdörster, E. (2006). Imposex in the intertidal snail Thais brevidentata (Gastropoda, Muricidae) from the Pacific coast of Costa Rica. Revista de Biología Tropical, 54(Suppl. 1), S21-S26.

Hammer, Ø., Harper, D. A. T., \& Ryan, P. D. (2001). PAST, Paleontological Statistics Software Package for Education and Data Analysis. Palaeontologia Electronica, 4, 1-9.

Holmes, R. W. (1970). The Secchi disk in turbid waters. Limnology, \& Oceanography, 15, 688-694.

Jiménez, C. (2001). Arrecifes y ambientes coralinos de Bahía Culebra, Pacífico de Costa Rica, aspectos biológicos, económico-recreativos y de manejo. Revista de Biología Tropical, 49(Supl. 2), S215-S231.

Jiménez, C., Cortés, J., León, A., \& Ruiz, E. (2001). Coral bleaching and mortality associated with the 1997-98 El Niño in an upwelling environment in the eastern Pacific (Gulf of Papagayo, Costa Rica). Bulletin of Marine Science, 69, 151-169.

Legendre, P., \& Gallagher, E. D. (2001). Ecologically meaningful transformations for ordinations of species data. Oecologia, 129, 271-280.

Lizano, O. G., \& Alfaro, E. (2004). Algunas características de las corrientes marinas en el Golfo de Nicoya,
Costa Rica. Revista de Biología Tropical, 52(Supl. 2), S77-S94.

Mallin, M. A., Pearl, H. W., Rudek, J., \& Bates, P. W. (1993). Regulation of estuarine primary production by watershed rainfall and river flow. Marine Ecology Progress Series, 93, 193-203.

Mata, A., Acuña, J. A., Murillo, M. M., \& Cortés, J. (1987). La contaminación por petróleo en el Caribe de Costa Rica, 1981-1985. Caribbean Journal of Science, 23, 41-49.

Meier, P. C., \& Zünd, R. E. (1993). Statistical Methods in Analytical Chemistry. New York, USA: John Wiley \& Sons, Inc.

Morales-Ramírez, A., Víquez, R., Rodríguez, K., \& Vargas, M. (2001). Marea roja producida por Lingulodinium polyedrum (Peridiniales, Dinophyceae) en Bahía Culebra, Golfo de Papagayo, Costa Rica. Revista de Biología Tropical, 49(Supl. 2), S19-S23.

Muller-Parker, G., \& Cortés, J. (2001). Spatial distribution of light and nutrients in some coral reefs of Costa Rica during January 1997. Revista de Biología Tropical, 49(Suppl. 2), S251-S263.

Palter, J., León-Coto, S., \& Ballestero, D. (2007). The distribution of nuttrients, dissolved oxygen and chlorophyll a in the upper Gulf of Nicoya, Costa Rica, a tropical estuary. Revista de Biología Tropical, 55, 427-36.

Riley, J. P., \& Chester, R. (1971). Introduction to Marine Chemistry. New York, USA: Academic Press.

Rixen, T., Jiménez, C., \& Cortés, J. (2012). Impact of upwelling events on the sea water chemistry in the Gulf of Papagayo (Culebra Bay), Costa Rica. Revista de Biología Tropical, 60(Suppl. 2), S187-S195.

Rojas-Figueroa, R. E., \& Vargas-Zamora, J. A. (2008). Abundancia, biomasa y relaciones sedimentarias de Americonuphis reesei (Polychaeta, Onuphidae) en el Golfo de Nicoya, Costa Rica. Revista de Biología Tropical, 56(Supl. 4), S59-S82.

Rodríguez-Sáenz, K., \& Morales-Ramírez, A. (2012). Composición y distribución del mesozooplancton en una zona de afloramiento costero (Bahía Culebra, Costa Rica) durante La Niña 1999 y el 2000. Revista de Biología Tropical, 60(Supl. 2), S143-S157.

Sibaja-Cordero, J. A., \& Vargas-Zamora, J. A. (2006). Zonación vertical de epifauna y algas en litorales rocosos del Golfo de Nicoya, Costa Rica. Revista de Biología Tropical, 54(Supl. 1), S49-S67.

Silva, A. M., \& Acuña-González, J. (2006). Caracterización físico-química de dos estuarios en la bahía de Golfito, Golfo Dulce, Pacífico de Costa Rica. Revista de Biología Tropical, 54(Supl. 1), S241-S256. 
Spongberg, A. L. (2004a). PCB contamination in surface sediments in the coastal waters of Costa Rica. Revista de Biología Tropical, 52(Suppl. 2), S1-S10.

Spongberg, A. L. (2004b). PCB concentrations in sediments from the Gulf of Nicoya estuary, Pacific coast of Costa Rica. Revista de Biología Tropical, 52(Suppl. 2), S11-S22.

Spongberg, A. L. (2004c). PCB contamination in marine sediments from Golfo Dulce, Pacific of Costa Rica. Revista de Biología Tropical, 52(Suppl. 2), S23-S32.

Spongberg, A. L. (2006). PCB concentrations in intertidal sipunculans (Phylum Sipuncula) from the Pacific of Costa Rica. Revista de Biología Tropical, 51(Suppl. 1), S27-S33.

Spongberg, A., \& Davis, P. (1998). Organochlorinated pesticide contaminants in Golfo Dulce, Costa Rica. Revista de Biología Tropical, 46(Suppl. 6), S111-S124.

Spongberg, A. L., \& Witter, J. D. (2008). A review of PCB concentrations in tropical media, 1996-2007. Revista de Biología Tropical, 56(Suppl. 4), S1-S9.

Spongberg, A. L., Witter, J. D., Acuña, J., Vargas, J., Murillo, M., Umaña, G., ... Perez, G. (2011). Reconnaissance of selected PPCP compounds in Costa Rican surface waters. Water Research, 45, 6709-6717.

Strickland, J. D. H., \& Parsons, T. R. (1972). A Pratical Handbook of Sewater Analysis. Fisheries Research Board of Canada Bulletin, 167, 1-310.

Svendsen, H., Rosland, R., Myking, S., Vargas, J. A., Lizano, O. G., \& Alfaro, E. J. (2006). A physical-oceanographic study of Golfo Dulce, Costa Rica. Revista de Biología Tropical, 54(Suppl. 1), S147-S170.

Valverde, R. A., Selcer, K. W., Lara, L. R., \& SibajaCordero, J. A. (2008). Lack of xenoestrogen-induced vitellogenin in male olive ridley sea turtles (Lepidochelys olivacea) from the Pacific coast of Costa Rica. Revista de Biología Tropical, 56(Suppl. 4), S49-S57.

Vargas, J. A. (2016). The Gulf of Nicoya estuarine ecosystem. In M. Kapelle (Ed.). Ecosystems of Costa Rica (pp. 106-124). Chicago, USA: University of Chicago Press.

Vargas, J. A., Acuña-González, J., Gómez, E., \& Molina, J. (2015). Metals in coastal mollusks of Costa Rica. Revista de Biología Tropical, 63(4), 1007-1019.

Vargas, J. A., Acuña-González, J., Vásquez, F., \& SibajaCordero, J. A. (2016). Brachiopods, sipunculans, enteropneusts and metals from two estuarine tidal flats, Pacific, Costa Rica. Revista de Biología Tropical, 64(3), 1311-1331.

Vargas, J. A., \& Dean, H. K. (2009). Sipunculans. In I. S. Wehrtmann, \& J. Cortés (Eds.). Marine Biodiversity of Costa Rica, Central America (pp. Text: 175-180, Species List: Compact Disc pp. 119-121). Berlin: Springer + Business Media B.V.

Vargas, J. A., \& Mata, A. (2004). Where the dry forest feeds the sea, the Gulf of Nicoya Estuary, In G. W. Frankie, A. Mata, \& S. B. Vinson (Eds.). Biodiversity Conservation in Costa Rica, Learning the Lessons in a Seasonal Dry Forest (pp. 126-135). California, USA: University of California Press.

Víquez, R., \& Hargraves, P. E. (1995). Annual cycle of potentially harmful dinoflagellates in the Gulf of Nicoya, Costa Rica. Bulletin of Marine Science, 57, 467-475.

Voorhis, A., Epifanio, C. E., Maurer, D., Dittel, A. I., \& Vargas, J. A. (1983). The estuarine character of the Gulf of Nicoya, an embayment on the Pacific coast of Central America. Hydrobiologia, 99, 225-237. 